\title{
The Industry 4.0, the Corporate Social Responsibility and the Impacts of Brand in the Digital Transformation
}

\author{
Genni Perlangeli ${ }^{1} \&$ Andrea Rea ${ }^{2}$ \\ ${ }^{1}$ Social Research and Marketing, Coris, Università degli studi di Roma, La Sapienza, Italy \\ ${ }^{2}$ Department of Digital Marketing \& Branding, Coris, Università degli studi di Roma, La Sapienza, Italy \\ Correspondence: Genni Perlangeli, Social Research and Marketing, Coris, Università degli studi di Roma, La \\ Sapienza, Italy. E-mail: jenny.perlangeli@gmail.com
}

$\begin{array}{lc}\text { Received: October 10, } 2021 & \text { Accepted: November 16, 2021 Online Published: November 19, } 2021 \\ \text { doi:10.5539/ijms.v13n4p54 } & \text { URL: https://doi.org/10.5539/ijms.v13n4p54 }\end{array}$

\begin{abstract}
The interest of my research is Digital Transformation and Corporate Social Responsibility as an involvement for the Brand.

In this way the "product platform" contributes to the improvement of competitive position of the Business Unit and Branding", between the marketing process: Customer Relationship Management_Product Development Management-Customer Satisfaction.

Weberian vision of ideal type as a concept — ideal limit to illustrate the significant elements of its own empirical content, tends to identify an overcoming from the role of consumer as target to the analysis of the techniques of profiling the humanization of the customer with his needs, fears and aspirations.

The research project consists of three parts. In the first a deepening on the wide literature of international scope, above all "made in USA" regarding the market orientation-Industry 4.0 - platform: the origin, the internal organization, the management, the communication strategies.

In the second part focuses instead on brand analysis, to reconstruct the main social and economic projects while assessing the internal analytical coherence, ideological value and deducing the most significant operational indications.

The third, on the other hand, explores corporate social responsibility through small and medium-sized enterprises with market orientation, a socially responsible management-driven approach, strategic enterprise orientation and business management, resulting from different synergistic combinations.
\end{abstract}

Keywords: corporate social responsibility, brand, project organization, digital transformation, digital platforms, corporate branding

\section{Introduction \& Research Design}

\subsection{Qualitative and Quantitative Analysis of International Literature}

In the recent years was an increase in web-based services with the common feature of connecting demand and supply for a specific purpose, enables by the rapid spread of digital and mobile technologies.

This paper is intended to illustrate the main economic and organizational aspects of the choice of a "platform" for the creation of the competitive advantage business; it is therefore placed in that vein of research, which studies the characteristics and effects of technological and management innovation. In an increasing number of industrial sectors, the dynamics of the main "competitive forces" (Porter, 1985, p. 11) the life cycle of a given model tends to shrink, while the number of innovations developed over a certain period of time increases.

The power of digital platforms to profitably disrupt industries continues to impress. Platform leaders like Amazon, Facebook, Airbnb, Uber and Google redefine user experience and expectations. Their ongoing success pushes incumbents to alternately revisit core business assumptions and seek regulatory relief (Marshall \& Schrange, 2016).

While pipeline businesses create value in a linear managerial way, platforms enable providers and consumers (sometimes the same people, as in peer-to-peer platforms) to create value through their own interactions. 'A 
platform's overarching purpose', write the authors, 'is to consummate matches among users and facilitate the exchange of goods, services, or social currency'. We can see connection as value creation through a variety of businesses in the internet age. Alibaba, Amazon and Etsy connect buyers and sellers through their online marketplaces. Facebook, Instagram, Twitter, Wikipedia, and YouTube became giant media platforms not by creating content, but by allowing users to generate content for each other (Coase, 1937).

As platforms move to embed digital technologies in the provision of real economic goods, they create value by 'de-linking' access from ownership, giving rise to the so-called sharing economy. The two greatest successes of the sharing economy so far, Airbnb and Uber, allow users to gain value from using a car or a home without having to own it. Airbnb creates value by matching private hosts with guests, facilitating payment between them through a trustworthy online system. Uber creates logistic value for drivers and passengers through its matching and pricing technology (Cohen, Hanh, Hall, Levitt, \& Metcalfe, 2016).

Sharing platforms may also help modern societies solve old problems, such as managing common resources in a more efficient way.

The sharing platforms "A farmer with a low-value crop might stop farming and sell his water to a farmer with a high-value crop, or to a municipal water authority within transport distance. As a result, when Australia was hit by drought starting in 2006, its farmers suffered far less than those in California have (Horton \& Zeckhauser, 2016).

Platforms (Diogo G.R. Costa) also create value by revolutionizing middlemen economies, Microsoft and Google sponsor their respective Windows and Android platforms while HP and Samsung provide the hardware that customers use to experience the platform. Platform sponsors often engender competition among providers who deal with customers to increase the affiliated user base; think how search engines powered by reviewers allow authors to bypass publishers through Amazon or jewellery makers to bypass stores via Etsy. Or how certifiers, such as Yelp or TripAdvisor users, have become more relevant than traditional guides. Digital distribution relies less on people and more on matching algorithms that have been proving to be more efficient than agents and advertisers. Platforms are creating what Munger (2015) calls a 'middlemen revolution' not because it eliminates middlemen, but because it replaces them with new kinds of intermediacy.

Platform Revolution is not alone in its attempt to explain the new economic world of the internet age. It follows a series of books such as "What is Mine is Yours" by Rachel Botsman and Roo Rogers (2010), "The Mesh" by Lisa Gansky (2010), and "The Sharing Economy" by Arun Sundararajan (2016), among the most notable examples of this literature. What distinguishes Platform Revolution in this conversation is that Parker et al. focus on the platforms themselves rather than on the market space created around them. They aim to produce an anatomy of a new business model rather than to model a new business environment.

There are different terms about these themes the 'sharing economy', the 'collaborative economy', the 'peer-to-peer economy', the 'gig economy', and so on.

Parker et al. in their book of 2016 write about "Revolution Platform" to identify the era in which we live, characterized by platforms are dominating the market in the most varied sectors transforming people's lives. The authors introduce the concept of "platform power" and define a business platform ad a new business model that connects people, organizations, and resources through technology in an interactive ecosystem in which incredible amounts of value can be created and shared (Parker et al., 2016). A business-platform is an architecture, based on hardware and software, that works as an aggregator (a hub) organizing, in an ecosystem and with network effects, resources, transactions and relationship between individuals and various actors such as a consumer-users, professionals, businesses, institutions, business partners, etc. to co-create value.

Another peculiarity is that in Platfirm, both assets and output value have moved outside the organization and are derived from the ability to orchestrate.

The brand is the aspect of my research as a source of trust through the digital platform connects the corporate social responsibility.

The brand is they can be built through engagement and relationships with the brand (Habibi et al., 2014); however, trust can also be transferred. Trust transfer occurs when initial trust in a target (a person, a group, or an organization) turns into trust in another target (Stewart, 2003). 


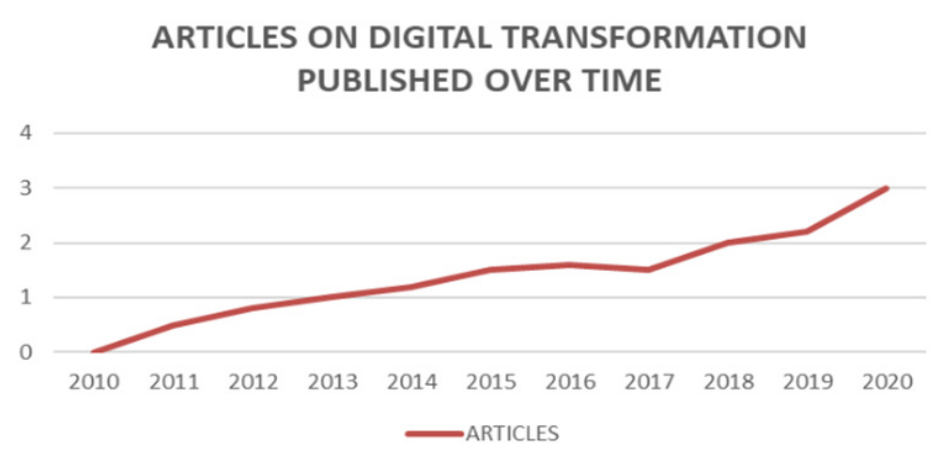

Figure 1. Articles on digital transformation published over time

As Figure 1 illustrates, the rise in interest in DT has been fast and recent. The number of publications dealing with DT has risen substantially over time. Indeed, 50 per cent of the 279 articles in the consideration set were published in the last five years. Figure 1 shows the cumulative number of articles on DT published between 2010 and 2020 within our sample.

\section{Materials and Methods}

\subsection{Analyzed Brands and Survey Design}

The study employs an online survey to measure the answer the measure the answer of the subjects.

The marketing is defined as "a social and managerial process designed to meet the needs and requirements through the processes of creating and exchanging products and values. It is the art and science of identifying, creating and delivering value to meet the needs of a target market, making a profit: delivery of satisfaction at a price" (Pallavicini, 2021).

The proliferation of digital technologies defined as the combination and connectivity of innumerable, dispersed information, communication, and computing technologies (Bharadwaj et al., 2013) contemporary organizations are both affected and need to adapt (e.g., Correani et al., 2020; Verhoef et al., 2019; Weill \& Woerner, 2018).

Therefore, the phenomenon is naturally connected to the topic of organizational change, viewed as a 'difference in form, quality, or state over time in an organizational entity' (Van de Ven \& Poole, 1995, p. 512). Thus, we define DT as organizational change that is triggered and shaped by the wide-spread diffusion of digital technologies. Such a view enables us to potentially explain the phenomenon of DT and its management in business practice by drawing on the robust and diversified knowledge base relating to organizational change and innovation (Poole \& Van de Ven, 2004).

The phenomenon of DT also seems to present an opportunity to advance the existing body of knowledge about organizational change. While prior research studied organizational change in relation to information technology (IT) (Markus \& Robey, 1988; Orlikowski, 2000; Volkoff et al., 2007), the latter defined as 'computer-based technology for the storage, accessing, processing and communication of information' (Molloy \& Schwenk, 1995, p. 283), and created valuable and persistent knowledge, recent observations suggest that DT deviates from these past organizational changes in at least the following ways.

First, the technologies in-volved, such as big data analytics, social media, mobile technology or cloud computing, seem very different from earlier IT (Bharadwaj et al., 2013).

Second, many digital technologies cannot be restricted to the boundaries of firms or industries but involve an ecosystem and the demand-side. (Tilson et al., 2010)

Third, the consequences of DT - such as the emergence of new digital business models - seem to extend beyond phases of IT change (e.g., Orlikowski, 2000).

Boundary conditions (BC) explored organizational research method (Whetten, 1989, p. 492; Busse et al., 2017): the empirical reality is changing and established theoretical models.

The systematic review (Tranfield et al., 2003) as the methodology for this study and proceeded in three steps: (1) data collection, (2) data analysis, and (3) synthesis (Crossan \& Apaydin, 2010).

Articles published in Google Scholar in 2021 are about "Digital Platform" about 61,600 results and 37,900 results are about "Corporate social responsibility". 
The study employed an online survey with five-point scales to measure the answer of the subjects. Overall, eight variables were considered: Brand congruence, Actual Self congruence, Ideal Self congruence, Involvement, Post Attitude, Post Belief and change in Brand Trust and Purchase Intention.

In my research a part of corporate social responsibility is implemented by the subjects interviewed also depends on the function of marketing, marketing and communication, marketing corporate social responsibility, human resources department (Caroli \& Tantalo, n.d.).

The behaviour model adopted by the undertaking has a direct impact not only on the company's reputation but also on the unit, having an ethical and responsible corporate orientation takes on a role of primary importance in the management of the company and is considered as the main guide in the planning, programming and implementation of the business strategy.

The corporate social responsibility is assumed as the reason of existence of the company and one of the distinctive characteristics of the company that still today represents a strong point on which to be able to leverage for the maintenance of the competitive advantage position acquired in the sector.

In a qualitative survey is customary to select a small and unrepresentative sample for interviews, group discussions or other methods of qualitative observation. The results are interpreted in relation to the context, this information being impossible to present quantitatively. It will be clear that qualitative research is less structured than quantitative research and this is the biggest difference between the two methods.

In a qualitative survey is customary to select a small and unrepresentative sample for interviews, group discussions or other methods of qualitative observation. The company through the platform is the object but not the source of the study and the corporate identity is the reality and uniqueness of an organization that relates directly to its external and international climate and its reputation through corporate communication (Gray \& Balmer, 1998)

Qualitative analysis allows to identify a series of nuances of a certain behavior or event that could not be grasped with a quantitative analysis.: focus group, interview, etnographic research.

The quantitative analysis with the drafting of the questionnaire allows to identify a series of feedback identified with the introduction of net promoter score, useful for carrying out comparative analysis. In the course of the pretest, the participants assessed eight brand scenarios for the perceived level of involvement on a six-item scale (identification, orientation, guarantee, personalization, playful function, practical function) adapted from Laurent and Kapferer (1985).

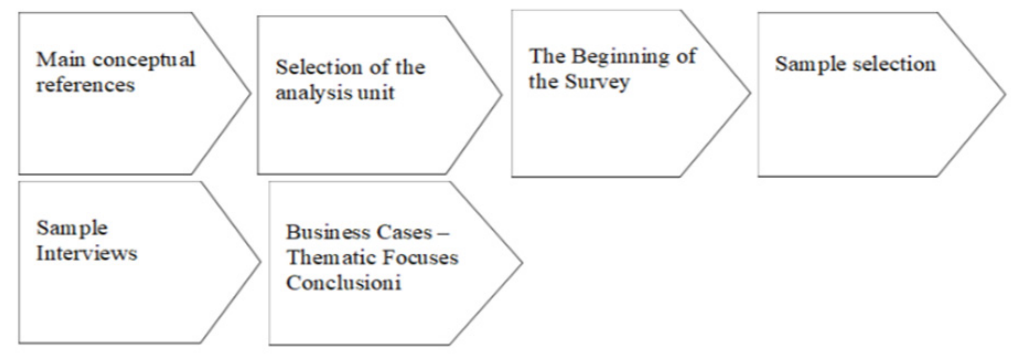

Figure 2. Phases in the research project

In the collection phase, a search was conducted for keywords in titles and abstract, in the main electronic databases for the field of social sciences: Business Source Premier (EBSCO), Emerald, Virtual Emeroteca, JSTOR, Science Direct (Elsevier), Social Science Research Network (SSRN), Web of Science, Wiley Interscience Journals (Wiley online library) and Sage Journals online. I did not choose "a priori" a reference period within which to define the scope of the survey, but in the desire to include as many studies as possible, albeit in the awareness that it cannot be exhaustive, each database has been interrogated in all its temporal extent. Search strings were composed Gathering -Search, by keywords in titles and abstracts with these keywords: Corporate social responsibility, brand, project organization, digital transformation, digital platforms, corporate branding. 
Table 1. Journal database used

\begin{tabular}{lllllll}
\hline DATABASE & CSR & & DT & \multicolumn{2}{c}{ Corporate Branding } \\
\cline { 2 - 7 } & Title & Abstract & Title & Abstract & Title & Abstract \\
\hline Business source premier - EBSCO & 94 & 223 & 42 & 220 & 0 & 26 \\
Emerald & 1 & 22 & 1 & 21 & 0 & 7 \\
Emeroteca Virtuale & 32 & 132 & 12 & 82 & 0 & 7 \\
JSTOR & 7 & 33 & 2 & 12 & 0 & 5 \\
Science Direct & 18 & 61 & 7 & 32 & 0 & 1 \\
Social Science Research Network & 8 & 74 & 5 & 109 & 0 & 4 \\
Web of Science & 43 & - & 23 & - & 3 & - \\
Wiley Interscience Journals & 34 & 115 & 13 & 67 & 0 & 8 \\
Sage Journals online & 3 & 20 & 3 & 36 & 0 & 2 \\
\hline
\end{tabular}

Among the results, published articles, working paper, conference proceedings and reports, for a total of 1088 jobs (Table 2), which you are received by checking that no work was inserted several times, because mentioned in more than one database or because it can be detected by more than one keywords. It was, in fact, possible to assess that as many as 110 contributions were identified with two different queries, 42 with three different queries, 6 with four queries and 3 with even five different queries.

The most present keywords are, therefore, "Corporate Social Responsibility*", "Digital Transformation*" and "Corporate Branding*".

Table 2. Type of contributions identified

\begin{tabular}{ll}
\hline Type & $\mathrm{Nr}$. \\
\hline Papers Published & 978 \\
Conference proceedings & 21 \\
Working paper & 14 \\
Papers not published e report & 75 \\
Tot & 1088 \\
\hline
\end{tabular}

In the phase of systematization, the 978 articles have gone back to the journals in which they were published (Table 2), thus being able to identify the most recurrent journals, which have turned out to be: Journal of Brand Management (85), Journal of Business Market Management and Journal of Business Economics and Management (28), followed by Journal of Business \& Economics (18), Journal of Business Research (16) Journal of Communication (14) and Journal of Communication Management (13) (2010-2020).

Table 3. Type of journal and match with keywords

\begin{tabular}{llll}
\hline TYPE & CSR & DT & Corporate Branding \\
\hline Journal of Product \& Brand Management & 275 & 32 & 762 \\
Journal of Business Market Management & 89,591 & 160,155 & 45,009 \\
Journal of Business Economics and Management & 88 & 21 & 46 \\
Journal of Business \& Economics & 112 & 32 & 43 \\
Journal of Business Research & 12550 & 7244 & 1964 \\
Journal of Communication & 754 & 352 & 145 \\
Journal of Communication Management & 2865 & 1281 & 1063 \\
\hline
\end{tabular}

Source: Data Research 2020/2021.

The 101 contributions identified in the systematic review process cover a period from 2010 to 2021. Most of the works, however, have been produced since 2015 (86 out of 101) and almost $50 \%$ only since 2018 , demonstrating the importance that the problem under consideration is assuming in recent years. The articles are in $81 \%$ of cases from international journals, mainly from Journal of Market Management, the remaining are conference proceedings and unpublished articles. Looking at the academic background of the authors, we highlight the origin of the same mainly from the field of corporate social responsibility, with a discreet representation of scholars related to the Communication. Most studies (86\%) are empirical-quantitative in nature and mainly adopts a hypothetical-deductive approach to test hypotheses, through the application, in $63 \%$ of cases, of 
regression models. Other recurring methodological approaches have been structural equation models and averaging differences tests Theoretical contributions, on the other hand, differ between literature review and paper of a purely conceptual nature.

\subsection{Sample of Research}

Table 4. Business segment

\begin{tabular}{llll}
\hline Business segment & \multicolumn{3}{c}{ Geographic area } \\
\hline HEALTH \& SPORT & $50 \%$ & ITALIA DEL NORD & $40 \%$ \\
INDUSTRY ELECTRONICS & $20 \%$ & ITALIA CENTRALE & $20 \%$ \\
WHOLESALE RETAIL & $10 \%$ & ITALIA DEL SUD & $10 \%$ \\
MUSEUM & $20 \%$ & EUROPA & $30 \%$ \\
\hline
\end{tabular}

Empirical studies (Table 4) focus mainly on samples of small and medium-sized enterprises, usually not in a specific sector: sometimes, in fact, there is a comparison between several sectors, but in most cases, studies do not provide for a sectoral distinction. From a geographical point of view, the report has been the subject of in-depth study in both developed and emerging countries. All areas of the World are represented, with a prevalence of studies conducted in Italy $(70 \%)$, Europe (30\%)

So I examine and develop the conceptual framework (Figure $3 \mathrm{a}-\mathrm{b}-\mathrm{c}$ ).

Weaken the effect of the congruence of corporate social responsibility on brand confidence in analysis 1 (Figure a).

In Analysis 2, I examine the effect of the congruence of the variables of corporate social responsibility, with those of the brand congruence, brand identity, brand trust intermediate variables and their impact on the trust of the brand. In analysis 3, I extend the conceptual model to examine the preponderant role of involvement on the relation between congruence of corporate social responsibility, Effective self-consciousness, and ideal self-consciousness on the one hand and the post and conviction attitude of the brand on the other, through the digital platforms of small and medium-sized enterprises.

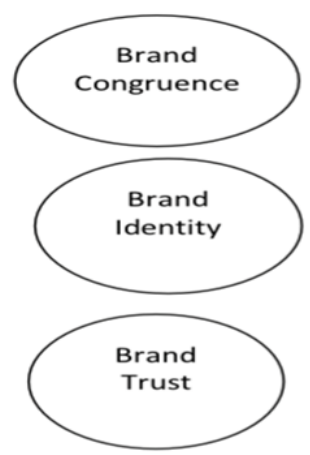

b

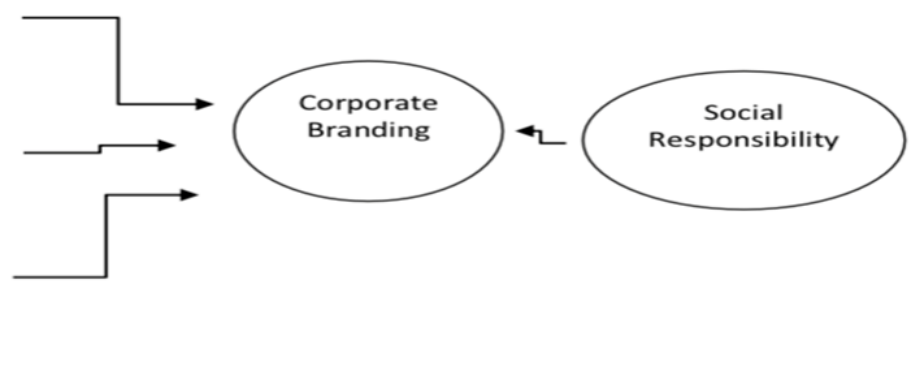

Figure 3. a. Walter von Mettenheim| Klaus-Peter Wiedmann - "The complex triad of congruence issues in influencer marketing" - Academic paper

\section{Conclusion}

Over time, the concept of corporate social responsibility has had wide scope for developing large business areas. In recent years the growing awareness of the fact that many small and medium-sized enterprises carry out activities that lead to focus on this issue even in the most modest contexts. The European Commission European Commission 2002 (Communication from the Commission on corporate social responsibility: a contribution from enterprises to sustainable development. Brussels, 2.7.2002) has identified the involvement of PMI in socially responsible policies as one of the priority objectives, given the importance of their role in the European economic context, with the prompt request to adapt the concept, corporate branding That's what research is all about. Demonstrate that moving from a philanthropic approach to a strategic and business approach (OCSE 
guidelines) brings greater positive or negative results to the corporate brand according to the parameters established by the following variables: brand identity, brand awareness, brand values, brand image, corporate reputation, credibility, community.

In the studies analyzed, it was found that the most cited theoretical approaches to explain the relationship between familiarity and performance are some of the theories consolidated in the management literature (O'Boyle et al., 2012): the resource-basedview (RBV) and steakeholder theory. In order to decode the complex framework of the report, the prevailing literature invites to reconcile theories and to use them in a complementary and multi-perspective perspective perspective (Sciarelli, 2007). The RBV is a theoretical framework, used as a reference model to identify complex and intangible resources as well as skills that condition an enterprise's ability to create value (Barney, 1986; Prahalad \& Hamel, 1990; Wernerfelt, 1984; Penrose, 1959). If they are inimitable, strongly rooted in the enterprise and adaptable to the dynamism of the environment, they represent a potential source of competitive advantage (Teece et al., 1997). The stakeholder theory (Freeman, 2007) instead goes on to mean as subjects "the individuals and groups on which the enterprise depends for its survival: shareholders, employees, customers, suppliers and key government agencies. In a broader sense, however, it is every well-identifiable individual who can influence or be influenced by the activity of the organization in terms of products, policies and work processes. In this broader sense, public interest groups, protest movements, local communities, government bodies, business associations, competitors, trade unions and the press, are all to be considered stakeholders". Clarkson (1995) extends the concept of stakeholder also to potential stakeholders such as future generations: "Stakeholders are persons or groups who have claims, title deeds, rights, or interests relating to an enterprise and its past, present and future activities". Important to such study is the proposed matrix structure from Hinna, obtained crossing the interest of every group of stakeholders with the influence that such group can exercise on the business activity. Therefore, those who govern the company are fully aware of their responsibility towards the groups and individuals towards whom their actions can generate effects or which can in turn influence such actions. The enterprise is seen as a network of relationships between groups that are stakeholders. The enterprise as a social institution with multiple aims must be oriented by those who govern it to the creation and dissemination of value for all those who have an interest in this process. The main entrepreneurial aim, then, is not the maximization of profit, but the creation of economic and social value through a wise management of the system of relationships that characterizes it in corporate social responsibility (Sciarelli, 2012).

\section{References}

Balmer, M. T., \& Gray, R. (2015). Corporate identity and corporate communications: Creating a competitive advantage. Emerald.

Barney, J. A. (1986). Organizational culture: Can it be source of sustained competitive advantage? Academy of Management Review, 11(3), 656-664. https://doi.org/10.2307/258317

Bharadwaj, A., El Sawy, O. A., Pavlou, P. A., \& Venkatraman, N. (2013). Digital business strategy: Toward a next generation of insights. MIS Quarterly, 37, 471-482. https://doi.org/10.25300/MISQ/2013/37:2.3

Bickerton, D. (2000). Corporate reputation versus corporate branding: The realist debate. Corporate Communications an International Journal, 5(1), 42-48. https://doi.org/10.1108/13563280010317578

Botsman, R., \& Rogers, R. (2010). What's Mine Is Yours: The Rise of Collaborative Consumption (1st ed.). New York: HarperBusiness.

Busse, C., Kach, A., \& Wagner, S. (2017). Boundary conditions: What they are, how to explore them, why we need them, and when to consider them. Organizational Research Methods, 20, 574-609. https://doi.org/10.1177/1094428116641191

Caroli, M., \& Tantalo, C. (n.d.). La responsabilità sociale di impresa nel quadro delle linee guida OCSE destinate alle imprese multinazionali.

Clarkson, M. B. E. (1995). A Stakeholder Framework for Analizing and Evaluating Corporate Social Performance. Academy of Management Review, 20, 92-117. https://doi.org/10.5465/amr.1995.9503271994

Coase, R. H. (1937). The Nature of the Firm. Economica, 4(16), 386-405. https://doi.org/10.1111/j.1468-0335.1937.tb00002.x

Cohen, P., Hahn, R., Hall, J., Levitt, S., \& Metcalfe, R. (2016). Using Big Data to Estimate Consumer Surplus: The Case of Uber. NBER Working Paper No. 22627. Cambridge. MA: National Bureau of Economic Research. https://doi.org/10.3386/w22627 
Correani, A., De Massis, A., Frattini, F., Petruzzelli, A., \& Natalicchio, A. (2020). Implementing a digital strategy: Learning from the experience of three digital transformation projetcs. California Management Review, 62, 37-56. https://doi.org/10.1177/0008125620934864

Costa, D. G. R. (2016). From pipelines to networks: The intellectual disruptions of online platforms. Economic Affairs, 36(30), 379-389. https://doi.org/10.1111/ecaf.12207

Crossan, M. M., \& Apaydin, M. (2010). A multi-dimensional framework of organizational innovation: A systematic review of the literature. Journal of Management Studies, 47, 1154-1191. https://doi.org/10.1111/j.1467-6486.2009.00880.x

European Commission. (2002). Communication from the Commission on corporate social responsibility: A contribution from enterprises to sustainable development. Brussels.

Freeman, E. R., Freeman, R. G., \& Dorigatti, M. (2007). Teoria degli stakeholder. FrancoAngeli.

Gansky, L. (2010). The Mesh: Why the Future of Business Is Sharing (reprint ed.). New York: Portfolio.

Habibi, M. R., Laroche, M., \& Richard, M. O. (2014). The roles of brand community and community engagement in building brand trust onsocial media. Computers in Human Behavior, 37, 152-161. https://doi.org/10.1016/j.chb.2014.04.016

Hinna, L. (2005). Come gestire la responsabilità sociale dell'impresa: manuale pratico - operativo, processi, strumenti e modelli, la rendicontazione del bilancio sociale. Il Sole 24 Ore, Milano.

Horton, J., \& Zeckhauser, R. (2016). Owning, Using and Renting: Some Simple Economics of the "Sharing Economy". Electronc Journal. https://doi.org/10.3386/w22029

Laurent, G., \& Kapferer, J. N. (1985). Measuring consumer involvementprofiles. Journal of Marketing Research, 22(1), 41-53. https://doi.org/10.1177/002224378502200104

Markus, M. L., \& Robey, D. (1988). Information technology and organizational change: Causal structure in theory and research. Management Science, 34, 583-598. https://doi.org/10.1287/mnsc.34.5.583

Marshall, W. V. A., \& Schrange, M. (2016). The best platforms are more than matchmakers. Hardvar Business Review.

Mettenheim, W., \& Wiedmann, K.-P. (2021). The complex triad of congruence issues in influencer marketing. Journal of Consumer Behaviour, 20(1). Retrieved August 26, 2021, from https://www.researchgate.net/publication/349478746_The_complex_triad_of_congruence_issues_in_influe ncer_marketing

Molloy, S., \& Schwenk, C. R. (1995). The Effects of Information Technology on Strategic Decision Making. Journal of Management Studies, 32(3), 283-311. https://doi.org/10.1111/j.1467-6486.1995.tb00777.x

Munger, M. (2015). The Third Entrepreneurial Revolution: A Middleman Economy. Retrieved September 17, 2015, from http://econ.as.nyu.edu/docs/IO/37424/Munger_Third_Entrepreneurial_Revolution2.pdf

O’Boyle Jr., E. H., Pollack, J. M., \& Rutherford, M. W. (2012). Exploring the relation between family involvement and firms financial performance: A meta-analysis of main and moderator effect. Journal of Business Venturing, 27(1), 1-18. https://doi.org/10.1016/j.jbusvent.2011.09.002

Orlikowski, W. J. (2000). Using technology and constituting structures: A practice lens for studying technology in organizations. Organization Science, 11, 367-472. https://doi.org/10.1287/orsc.11.4.404.14600

Orlikowski, W. J. (n.d.). The Duality of Technology: Rethinking the Concept of Technology in Organizations.

Pallavicini, G. (2021). Comparatively study of Marketing of Milk and milk products in Latur District. Asian Journal of Management Sciences.

Parker, G., Van, A., \& Marshall, W. (2014). Platform Strategy (April 21, 2014). The Palgrave Encyclopedia of Strategic Management, Available at SSRN.

Parker, G. G., Van Alystine, M. W., \& Choudary, S. P. (2016). Platform Revolution: How Networked Markets Are Transforming the Economyand How to Make Them Work for You. WW Norton and Company.

Poole, M., \& Van de Ven, A. (2004). Handbook of Organizational Change and Innovation. New York: Oxford University Press.

Porter, M. E. (1985). Il vantaggio competitivo, Milano, Edizioni di Comunità, 1987 (trad. ita. Di Competitive Advantage). New York: The Free Press. 
Prahalad, C. K., \& Hamel, G. (1990). The core competence of the corporation. HBR, 66(3), 79-91.

Sciarelli, M. (2012). Corporate Social Performance. Cedam, Padova.

Sciarelli, S. (2007). Etica e responsabilità sociale nell'impresa. Giuffrè, Milano.

Stewart, K. J. (2003). Trust transfer on the world wide web. Organization Science, 14(1), 5-17. https://doi.org/10.1287/orsc.14.1.5.12810

Sundarajan, A. (2016). The Sharing Economy: The End of Employment and the Rise of Crowd-Based Capitalism. Cambridge, MA: MIT Press.

Teece, D. J., Pisano, G., \& Shuen, A. (1997). Dynamic capabilities and strategic management. Strategic Management Journal, 18(7), 509-533. https://doi.org/10.1002/(SICI)1097-0266(199708)18:7<509::AID-SMJ882>3.0.CO;2-Z

Tilson, D., Lyytinen, K., \& Sarensen, C. (2010). Commento di ricerca - Infrastrutture digitali: L'agenda di ricerca IS mancante. Information Systems Research, 21, 748-759. https://doi.org/10.1287/isre.1100.0318

Tranfield, D., Denyer, D., \& Smart, P. (2003). Towards a methodology for developing evidence-informed management knowledge by means of systematic review. British Journal of Management, 14, 207-222. https://doi.org/10.1111/1467-8551.00375

Van De Ven, A., \& Poole, M. (1995). Explaining development and change in organizations. Academy of Management Review, 20, 510-540. https://doi.org/10.2307/258786

Verhoef, P., Broekhuizen, T., Bart, Y., Bhattachraya, A., Qi-Dong, J., Fabian, N., \& Haenlei, M. (2019). Digital transformation: A multidisciplinary reflection and research agenda. Journal of Business Research, in press.

Volkoff, O., Strong, D. M., \& Elmes, M. B. (2007). Radicamento tecnologico e cambiamento organizzativo. Organization Science, 18(5), 832-848. https://doi.org/10.1287/orsc.1070.0288

Weill, P., \& Woerner, S. (2018). Is your company ready for a digital future. MIT Sloan Management Review, Winter, 21-25.

Wernefelt, B. (1984). A resource-based view of the firm. Strategic Management Journal, 5(2), 171-180. https://doi.org/10.1002/smj.4250050207

Whetten, D. (1989). What constitutes a theoretical contribution? Academy of Management Review, 14(4), 490. https://doi.org/10.5465/amr.1989.4308371

\section{Copyrights}

Copyright for this article is retained by the author, with first publication rights granted to the journal.

This is an open-access article distributed under the terms and conditions of the Creative Commons Attribution license (http://creativecommons.org/licenses/by/4.0/). 